(2) Open Access Full Text Article

\title{
Impact of prostaglandin glaucoma drops on platelet-activating factor action: an in vitro study
}

This article was published in the following Dove Press journal:

Drug Design, Development and Therapy

7 December 2016

Number of times this article has been viewed

\section{Marilita M Moschos' \\ Eirini Nitoda' \\ Irini P Chatziralli' \\ Georgios D Panos ${ }^{2}$ \\ Constantinos A \\ Demopoulos ${ }^{3}$}

'Ist Department of Ophthalmology, Medical School, National and Kapodistrian University of Athens, Athens, Greece; ${ }^{2}$ Department of Ophthalmology, Geneva University Hospitals (HUG), University of Geneva, Geneva, Switzerland; ${ }^{3}$ Laboratory of Biochemistry, National and Kapodistrian University of Athens, Athens, Greece
Correspondence: Marilita M Moschos Ist Department of Ophthalmology, Medical School, National and Kapodistrian University of Athens, 6, Ikaria Street, Ekali, Athens I4578, Greece

Tel +306944887319

$\mathrm{Fax}+302104122319$

Email moschosmarilita@yahoo.fr
Aim: The aim of this study was to investigate the effect of different prostaglandin analogs on platelet-activating factor (PAF) levels.

Methods: Three prostaglandin analogs were selected: bimatoprost $0.3 \mathrm{mg} / \mathrm{mL}$, latanoprost $50 \mu \mathrm{g} / \mathrm{mL}$, and tafluprost $15 \mu \mathrm{g} / \mathrm{mL}$. Each drug sample was tested for its ability to cause platelet aggregation, which was measured as PAF-induced aggregation, before and after the addition of various concentrations of the examined sample, creating a linear curve of percentage inhibition (ranging from $0 \%$ to $100 \%$ ) versus different concentrations of the sample. The concentration of the sample that inhibited 50\% PAF-induced aggregation was calculated based on this curve, and this value was defined as IC50. In addition, the effect of eye drops on PAF metabolism was examined, through an in vitro analysis on PAF basic metabolic enzymes (PAF-cholinephosphotransferase, PAF-acetyl-CoA:1-O-alkyl-sn-glycero-3-phosphocholine acetyltransferase, and PAF-acetylhydrolase).

Results: The IC50 values for Lumigan UD ${ }^{\circledR}$ (bimatoprost $0.3 \mathrm{mg} / \mathrm{mL}$ ), Monoprost ${ }^{\circledR}$ (latanoprost $50 \mu \mathrm{g} / \mathrm{mL}$ ), and Saflutan (tafluprost $15 \mu \mathrm{g} / \mathrm{mL}$ ) were 8.7, 0.28 , and $1.4 \mu \mathrm{g} / \mathrm{mL}$, respectively.

Discussion: All three prostaglandin analogs suspended PAF, but bimatoprost induced the most potent inhibition, compared to tafluprost and to the weak effect of latanoprost.

Keywords: glaucoma, platelet-activating factor, prostaglandin analogs, treatment, platelet aggregation

\section{Introduction}

Glaucoma is estimated to be the second leading cause of severe vision loss and blindness worldwide, affecting $\sim 60.5$ million people and accounting for $2.65 \%$ of the population aged $>40$ years in 2010. ${ }^{1,2}$ The medical treatment for glaucoma includes prostaglandin analogs, which are approved as the first-line treatment for glaucoma in the European Glaucoma Society guidelines, carbonic anhydrase inhibitors, $\beta$-receptor antagonists, adrenergic agonists, and parasympathomimetics. ${ }^{3,4}$ Prostaglandins are a family of lipid compounds that are derived enzymatically from essential fatty acids, with each containing 20 carbon atoms, including a 5-carbon ring. ${ }^{5}$ In eye, they are synthesized by the trabecular endothelial and the ciliary muscle cells from membrane phospholipids and arachidonic acid, exhibiting anti-inflammatory action. ${ }^{6,7}$ They seem to alter both the function and structure of the uveoscleral pathways, inducing extracellular matrix remodeling, widening of the intermuscular spaces, and dissolution of collagens types I and III. ${ }^{8}$ Besides prostaglandin E2, various inflammatory molecules, including cytokines, cyclooxygenase 2, tumor necrosis factor-alpha, interleukins, platelet-activating factor (PAF), vascular endothelial growth factor, and C-reactive protein have been implicated in the mechanisms of glaucoma, highlighting the role of inflammation in the pathogenesis of the disease..$^{9,10}$ 
PAF (1-0-alkyl-2-acetyl-sn-gluceryl-3phosphorylcholine) is a low-molecular phospholipid mediator that is involved in inflammatory process acting on various types of cells through specific receptors. Two metabolic pathways are responsible for PAF secretion: 1) de novo synthesis, where PAF is produced by a lipid intermediate (1-0-alkyl-2-acetyl-sn-glycerol), through the action of the enzyme cholinephosphotransferase (PAF-CPT), converting cytidine diphosphate-choline (CDPcholine) to cytidine monophosphate; and 2) remodeling pathway, which is activated under inflammatory conditions and results in the secretion of PAF from preexisting membranebound ether-linked phospholipids through the enzyme acetyl-CoA:1-O-alkyl-sn-glycero-3-phosphocholine acetyltransferase (lyso-PAF-AT), which transfers an acetyl group in the sn-2 position of lyso-PAF. ${ }^{11,12}$ In the remodeling pathway, when cytosolic phospholipase A2 is activated, it becomes membrane-associated and hydrolyzes the fatty acyl moiety esterified at the sn-2 position of membrane phospholipids. The subsequent release of 2-lyso-phospholipids (1-radylsnglycero-3-phosphocholine or lyso-choline-containing membrane phospholipids) serves as substrates for the activation of PAF-acetylhydrolase (PAF-AH). ${ }^{13}$ The latter represents a heterogeneous group of PLA2 that removes sn-2 acetyl group, without affecting normal membrane phospholipids; they are responsible for the hydrolysis, the inactivation, and the concentrations of PAF in plasma and tissues. ${ }^{14}$

The activation of PAF requires its coupling with its receptor, which is a 7-transmembrane-G-protein-coupled receptor, located in a great variety of cells, including monocytes, lymphocytes, vascular endothelial and smooth muscle cells, renal and mesangial cells, hepatocytes, keratinocytes, and osteoclasts. ${ }^{11,13}$ The range of cell responses to PAF explains its role in both physiological processes, such as platelet aggregation and secretion, activation of neutrophils and macrophages, and pathological mechanisms, resulting in asthma, systemic or cardiac anaphylaxis, endotoxin-induced shocks, thrombosis, and gastrointestinal ulceration. ${ }^{11}$ The detection of PAF in ocular tissues, such as iris, ciliary body, retina, and vascular endothelium, confirms its implication in ocular inflammation and blood flow. ${ }^{15}$

Regarding the inflammatory background of glaucoma and the implication of PAF in the ocular inflammation and in the glaucomatous neuronal damage, the effect of different prostaglandin analogs on PAF levels was investigated.

\section{Materials and methods} Equipment and solutions

The following equipment was used in the present study:

1. Heraeus ${ }^{\circledR}$ Labofuge ${ }^{\circledR} 400 \mathrm{R}$ for centrifugations
2. Supersonic Bandelin Sonopuls HD 2070 sonicator (Heinrichstraze 3-4, Berlin, Germany) for homogenizations (30\% of the power)

3. 1209 Rackbeta (Pharmacia, Wallac, Finland) as liquid scintillation counter

4. Chrono-Log model $400 \mathrm{VS}$ aggregometer (Havertown, PA, USA) to study platelet aggregation.

The eye drops tested in the present study were as follows: Lumigan UD ${ }^{\circledR}$ (bimatoprost $0.3 \mathrm{mg} / \mathrm{mL}$; Allergan Pharmaceuticals Ltd., Westport, Ireland), Monoprost ${ }^{\circledR}$ (latanoprost $50 \mu \mathrm{g} / \mathrm{mL}$; Laboratoires Thea, Clermont-Ferrand, France), and Saflutan (tafluprost $15 \mu \mathrm{g} / \mathrm{mL}$; Vianex S.A., Athens, Greece).

\section{Calculation of the inhibitory effects of sample on PAF-induced aggregation}

This is an in vitro study, where no human or animal subjects are included, but blood samples was required. The ethics committee of the General Hospital of Athens G. Gennimatas approved the protocol. Because the study was an in vitro one, no patient informed consent was needed. A total of $9 \mathrm{~mL}$ of blood was collected from the marginal ear vein of a New Zealand White rabbit and added in $1 \mathrm{~mL}$ of an anticoagulant solution of sodium citrate/citric acid. The sample was centrifuged at $630 \times g$ for $13 \mathrm{~min}$ at $25^{\circ} \mathrm{C}$, and the supernatant was subsequently centrifuged at $1,400 \times \mathrm{g}$ for $20 \mathrm{~min}$ at $25^{\circ} \mathrm{C}$ in order to obtain plasma (rich in platelets). The isolation of plasma and leukocytes from blood samples and the biological assay on washed rabbit platelets were carried out according to the methods described by Moschos et al. ${ }^{16-19}$ The leukocytes were isolated after the sedimentation of the erythrocytes using $3.4 \mathrm{~mL}$ of dextran solution (3\% dextran in $0.15 \mathrm{M} \mathrm{NaCl}$ ) for $1 \mathrm{~h}$ at room temperature. The homogenates of leukocytes were aliquoted and stored at $-80^{\circ} \mathrm{C}$ after protein determination by using Bradford method.

Briefly, PAF and the examined drug samples were dissolved in $12.5 \mathrm{mg}$ of bovine serum albumin (BSA) per $1 \mathrm{~mL}$ of saline. The ability of each selected drug to cause platelet aggregation was estimated by adding various concentrations of each sample into the platelet suspension. The PAF-induced aggregation was calculated at baseline ( $0 \%$ inhibition) and after the addition of the examined samples (in a variety of concentrations), and a linear curve of the percentage inhibition to the concentrations of each sample was created. The concentration of the sample that inhibited $50 \%$ of the PAFinduced aggregation was defined as IC50.

\section{Determination of PAF and biosynthetic enzymes activities}

The extraction, purification, and determination of PAF were transacted according to the methods described previously. ${ }^{19-21}$ 
PAF was extracted according to the Bligh-Dyer method and was separated by a thin-layer chromatography (TLC) on silica gel G-coated plates with a development system consisting of chloroform/methanol/acetic acid/water (100:57:16:8, v/v/ $\mathrm{v} / \mathrm{v})$. The specific activities of PAF-CPT and lyso-PAF-AT were expressed as pmol of produced $\mathrm{PAF} / \mathrm{min} / \mathrm{mg}$ of sample protein present in each assay.

The homogenate of leukocytes, isolated from New Zealand white rabbits, was used to perform the PAF-CPT and lyso PAF-AT activity assays, as described previously. ${ }^{18-20,22}$ The PAF-CPT activity assay was carried out at $37^{\circ} \mathrm{C}$ for $20 \mathrm{~min}$ in a final volume of $200 \mu \mathrm{L}$, started by the addition of CDP-choline and stopped by the addition of $0.5 \mathrm{~mL}$ of cold methanol after $20 \mathrm{~min}$. The reaction of lyso PAF-AT was carried out at $37^{\circ} \mathrm{C}$ for $30 \mathrm{~min}$ in a final volume of $200 \mathrm{~mL}$, started with the addition of the homogenated sample and was stopped by adding $0.5 \mathrm{~mL}$ of cold methanol after $30 \mathrm{~min}$. Plasma PAF-AH was determined in plasma isolated from New Zealand white rabbits by the trichloroacetic acid precipitation method by using $\left[{ }^{3} \mathrm{H}\right]$ PAF as a substrate. ${ }^{23}$ Protein concentrations were measured based on BSA as the protein standard (method of Bradford). ${ }^{17}$

\section{Statistical analysis}

The Statistical Package for the Social Sciences Version 17.0 (SPSS Inc., Chicago, IL, USA) was used for the analysis. The IC50 values were expressed as mean.

\section{Results}

The concentration of the bioactive compound that inhibited $50 \%$ of the PAF-induced aggregation in the aggregometer cuvette was defined as IC50 and expressed in $\mu \mathrm{g} / \mathrm{mL}$. The IC50 of the tested eye drops indicated that the present substances are considered good inhibitors for PAF, acting in the range of $\mu \mathrm{M}$. The IC50 values for bimatoprost $0.3 \mathrm{mg} / \mathrm{mL}$, latanoprost $50 \mu \mathrm{g} / \mathrm{mL}$, and tafluprost $15 \mu \mathrm{g} / \mathrm{mL}$ were 8.7 , 0.28 , and $1.4 \mu \mathrm{g} / \mathrm{mL}$, respectively. These values indicated that all tested substances achieved to inhibit PAF.

\section{Discussion}

The effect of the three prostaglandins, bimatoprost, latanoprost, and tafluprost, on PAF activity was investigated, evaluating the aggregation of platelets. It was noted that all the three prostaglandins suspended PAF, but bimatoprost induced the most potent inhibition (IC50 $=8.7 \mu \mathrm{g} / \mathrm{mL}$ ) compared to tafluprost (IC50 $=1.4 \mu \mathrm{g} / \mathrm{mL}$ ) and to the weak effect of latanoprost ( $\mathrm{IC} 50=0.28 \mu \mathrm{g} / \mathrm{mL}$ ). Latanoprost was launched in 1996 and was the first of the currently available topical $\mathrm{PGF}_{2 \alpha}$ analogs for glaucoma treatment. It is an esterified prodrug of $\mathrm{PGF}_{2 \alpha}$ and, as such, is more lipophilic than the parent compound. ${ }^{24}$ Bimatoprost is a synthetic structural prostaglandin $\mathrm{F}_{2 \alpha}$ analog, where the carboxylic acid is replaced by a neutral ethylamide, but it has low direct effect on prostaglandin $\mathrm{F}_{2 \alpha}$ receptors. ${ }^{25}$ Comparative studies revealed that bimatoprost has a greater hypotonic effect compared to latanoprost, whereas Noecker et al revealed only statistical but not clinical significance of bimatoprost versus latanoprost. ${ }^{26-28}$

Tafluprost, which is the first preservative-free prostaglandin medication developed for the treatment of glaucoma, is a prodrug of synthetic analog of prostaglandin $\mathrm{F}_{2 \alpha}$. It exhibits high affinity and selectivity with prostaglandin $\mathrm{F}$ prostanoid receptors, while it also binds to the prostanoid EP3 receptor, amplifying its hypotonic action. ${ }^{29,30}$ Kurashima et al supported that tafluprost limits ciliary artery contraction, inducing a superior hypotensive effect compared to latanoprost. ${ }^{31}$ Yamada et al noted that bimatoprost induced greater expression of metalloproteinase 2 (MMP-2) and metalloproteinase 3 (MMP-3) than latanoprost and tafluprost, whereas tafluprost and latanoprost increased the expression MMP-1 and MMP-9, respectively, more than bimatoprost. ${ }^{32}$ In a previous study, it was found that latanoprost (IC50 =0.29 $\mu \mathrm{M}$ ) was found to be the most potent in inhibiting PAF compared to single travoprost (IC50 $=0 \mu \mathrm{M}$ ) or to the combination of the latter with timolol $(\mathrm{IC} 50=0.11 \mu \mathrm{M}) .{ }^{19}$

Jager et al had previously observed that the accumulation of PAF in the aqueous humor of rabbits was implicated by the increase of intraocular pressure. Moreover, they supported that the systemic administration of a PAF-antagonist (BN 52021) prevented the raise of intraocular pressure. ${ }^{33}$ It has already been revealed that the binding of PAF with its receptor results in the activation of PLA2 and phospholipases C, D, P, and A2; releasing arachidonic acid; prostaglandin metabolites; and protein kinase $C .{ }^{34} \mathrm{PAF}$ also stimulates the expression of selective MMPs, whose levels and activity seem to be increased in the iris/ciliary body of mice with pigmentary glaucoma. ${ }^{35,36}$

The present study concluded that all prostaglandin analogs suspended PAF. However, bimatoprost seems to have a potent inhibitory action against PAF compared to the moderate effect of tafluprost and the weak action of latanoprost. It was also concluded that bimatoprost can efficiently eliminate the inflammatory process that takes place in glaucomatous lesions, eliminating the concentrations of PAF.

\section{Acknowledgment}

No financial support was offered for the present study.

\section{Author contributions}

All authors contributed toward data analysis, drafting and revising the paper and agree to be accountable for all aspects of the work. 


\section{Disclosure}

The authors report no conflicts of interest in this work.

\section{References}

1. Resnikoff S, Pascolini D, Etya'ale D, et al. Global data on visual impairment in the year 2002. Bull World Health Organ. 2004;82:844-851.

2. Quigley HA, Broman AT. The number of people with glaucoma worldwide in 2010 and 2020. Br J Ophthalmol. 2006;90:262-267.

3. Schmidl D, Schmetterer L, Garhöfer G, Popa-Cherecheanu A. Pharmacotherapy of glaucoma. J Ocul Pharmacol Ther. 2015;31(2):63-77.

4. European Glaucoma Society. Terminology and Guidelines for Glaucoma. 3rd ed. Savona: Dogma; 2008.

5. Komoto J, Yamada T, Watanabe K, Woodward DF, Takusagawa F. Prostaglandin F2alpha formation from prostaglandin $\mathrm{H} 2$ by prostaglandin F synthase (PGFS): crystal structure of PGFS containing bimatoprost. Biochemistry. 2006;45(7):1987-1996.

6. Polansky JR, Kurtz RM, Alvarado JA, Weinreb RN, Mitchell MD. Eicosanoid production and glucocorticoid regulatory mechanisms in cultured human trabecular meshwork cells. Prog Clin Biol Res. 1989; 312:113-138.

7. Matsumoto S, Yorio T, Magnino PE, DeSantis L, Pang IH. Endothelininduced changes of second messengers in cultured human ciliary muscle cells. Invest Ophthalmol Vis Sci. 1996;37(6):1058-1066.

8. Lütjen-Drecoll E, Tamm E. Morphological study of the anterior segment of cynomolgus monkey eyes following treatment with prostaglandin F2 alpha. Exp Eye Res. 1988;47(5):761-769.

9. Vohra R, Tsai JC, Kolko M. The role of inflammation in the pathogenesis of glaucoma. Surv Ophthalmol. 2013;58(4):311-320.

10. Bazan NG, Allan G. Signal transduction and gene expression in the eye: a contemporary view of the pro-inflammatory, anti-inflammatory and modulatory roles of prostaglandins and other bioactive lipids. Surv Ophthalmol. 1997;41(Supp1 2):S23-S34.

11. Chao W, Olson MS. Platelet-activating factor: receptors and signal transduction. Biochem J. 1993;292:617-629.

12. Fragopoulou E, Iatrou C, Demopoulos CA. Characterization of acetylCoA: lyso-PAF acetyltransferase of human mesangial cells. Mediators Inflamm. 2005;2005(5):263-272.

13. McManus LM, Pinckard RN. PAF, a putative mediator of oral inflammation. Crit Rev Oral Biol Med. 2000;11(2):240-258.

14. Derewenda ZS, Derewenda U. The structure and function of platelet-activating factor acetylhydrolases. Cell Mol Life Sci. 1998;54: 446-455.

15. Rosenbaum JT, Boney RS, Samples JR, Valone FH. Synthesis of platelet activating factor by ocular tissue from inflamed eyes. Arch Ophthalmol. 1991;109(3):410-413.

16. Tsoupras AB, Chini M, Mangafas N, et al. Platelet activating factor and its basic metabolic enzymes in blood of naive HIV-infected patients. Angiology. 2012;63:343-352.

17. Bradford MM. A rapid and sensitive method for the quantization of microgram quantities of protein utilizing the principle of protein-dye binding. Anal Biochem. 1976;72:248-254.

18. Antonopoulou S, Fragopoulou E, Karantonis HC, et al. Effect of traditional Greek Mediterranean meals on platelet aggregation in normal subjects and in patients with type 2 diabetes mellitus. J Med Food. 2006;9:356-362.

19. Moschos MM, Chatziralli IP, Stamatakis G, Papakonstantinou VD, Tsatsos M, Demopoulos CA. In vitro effects of anti-glaucomatous eye drops on platelet activating factor and its metabolism. Semin Ophthalmol. Epub 2015 Aug 13.
20. Tsoupras AB, Fragopoulou E, Nomikos T, Iatrou C, Antonopoulou S, Demopoulos CA. Characterization of the de novo biosynthetic enzyme of platelet activating factor, DDT insensitive cholinephosphotransferase, of human mesangial cells. Mediators Inflamm. 2007;2007:27683.

21. Tsoupras AB, Chini M, Tsogas N, et al. Anti-platelet activating factor effects of highly active antiretroviral therapy (HAART): a new insight in the drug therapy of HIV infection? AIDS Res Hum Retroviruses. 2008;24:1079-1086.

22. Gimenez R, Aguilar J. Cytidine (5') diphosphocholine induced decrease in cerebral platelet activating factor is due to inactivation of its synthesizing enzyme cholinephosphotransferase in aged rats. Neurosci Lett. 2001;299:209-212.

23. Antonopoulou $\mathrm{S}$, Demopoulos $\mathrm{CA}$, Iatrou $\mathrm{C}$, Moustakas $\mathrm{G}$, Zirogiannis $\mathrm{P}$. Platelet activating factor acetylhydrolase (PAF-AH) in human kidney. Int J Biochem. 1994;26:1157-1162.

24. Ota T, Aihara M, Narumiya S, Araie M. The effects of prostaglandin analogues on IOP in prostanoid FP-receptor-deficient mice. Invest Ophthalmol Vis Sci. 2005;46:4159-4163.

25. Woodward DF, Krauss AH, Chen J, et al. Pharmacological characterization of a novel antiglaucoma agent, Bimatoprost (AGN 192024). J Pharmacol Exp Ther. 2003;305(2):772-785.

26. Gandolfi S, Simmons ST, Sturm R, Chen K, VanDenburgh AM; Bimatoprost Study Group 3. Three-month comparison of bimatoprost and latanoprost in patients with glaucoma and ocular hypertension. Adv Ther. 2001;18(3):110-121.

27. Konstas AG, Katsimbris JM, Lallos N, Boukaras GP, Jenkins JN, Stewart WC. Latanoprost $0.005 \%$ versus bimatoprost $0.03 \%$ in primary open-angle glaucoma patients. Ophthalmology. 2005;112(2):262-266.

28. Noecker RS, Dirks MS, Choplin NT, Bernstein P, Batoosingh AL, Whitcup SM; Bimatoprost/Latanoprost Study Group. A six-month randomized clinical trial comparing the intraocular pressure-lowering efficacy of bimatoprost and latanoprost in patients with ocular hypertension or glaucoma. Am J Ophthalmol. 2003;135(1):55-63.

29. Uusitalo H, Egorov E, Kaarniranta K, Astakhov Y, Ropo A. Benefits of switching from latanoprost to preservative-free tafluprost eye drops: a meta-analysis of two Phase IIIb clinical trials. Clin Ophthalmol. 2016; 10:445-454.

30. Ota T, Aihara M, Saeki T, Narumiya S, Araie M. The IOP-lowering effects and mechanism of action of tafluprost in prostanoid receptordeficient mice. Br J Ophthalmol. 2007;91(5):673-676.

31. Kurashima H, Watabe H, Sato N, Abe S, Ishida N, Yoshitomi T. Effects of prostaglandin $F(2 \alpha)$ analogues on endothelin-1-induced impairment of rabbit ocular blood flow: comparison among tafluprost, travoprost, and latanoprost. Exp Eye Res. 2010;91(6):853-859.

32. Yamada H, Yoneda M, Gosho M, Kato T, Zako M. Bimatoprost, latanoprost, and tafluprost induce differential expression of matrix metalloproteinases and tissue inhibitor of metalloproteinases. $B M C$ Ophthalmol. 2016;16:26.

33. Jager GV, van Delft JL, van Haeringen NJ, Verbeij NL, Braquet P. Antagonist of platelet-activating factor prevents prostaglandin E2 induced ocular hypertension in rabbits. Prostaglandins. 1993;45(1):97-105.

34. Shukla SD. Platelet-activating factor receptor and signal transduction mechanisms. FASEB J. 1992;6:2296-2301.

35. Bazan H, Ottino P. The role of platelet-activating factor in the corneal response to injury. Prog Retin Eye Res. 2002;21:449-464.

36. Zhou X, Li F, Kong L, Tomita H, Li C, Cao W. Involvement of inflammation, degradation, and apoptosis in a mouse model of glaucoma. J Biol Chem. 2005;280(35):31240-31248. 


\section{Publish your work in this journal}

Drug Design, Development and Therapy is an international, peerreviewed open-access journal that spans the spectrum of drug design and development through to clinical applications. Clinical outcomes, patient safety, and programs for the development and effective, safe, and sustained use of medicines are the features of the journal, which has also been accepted for indexing on PubMed Central. The manuscript management system is completely online and includes a very quick and fair peer-review system, which is all easy to use. Visit http://www.dovepress.com/testimonials.php to read real quotes from published authors.

Submit your manuscript here: http://www.dovepress.com/drug-design-development-and-therapy-journal 